\title{
Aktivitas Antimikroba Lactobacillus sp. yang Diisolasi dari Feses Bayi Terhadap Pertumbuhan Bakteri Salmonella typhi
}

\author{
Dian Firmansyah ${ }^{1)}$, *Iis Herawati' ${ }^{2}$, Prima Nanda Fauziah ${ }^{3)}$ \\ ${ }^{1}$ Rumah Sakit Abdul Radjak Purwakarta \\ ${ }^{2}$ Teknologi Laboratorium Medis, Sekolah Tinggi Ilmu Kesehatan Jenderal Achmad Yani Cimahi \\ ${ }^{3}$ Prodi Analis Kesehatan, Fakultas Kesehatan, Universitas Mohammad Husni Thamrin, Jakarta \\ *Correspodence author: Iis Herawati, iis.herawati73@yahoo.com, Cimahi, Indonesia
}

\begin{abstract}
Abstrak
Bakteri asam laktat telah digunakan sebagai pengawet makanan, kultur fermentasi dan pangan probiotik karena mempunyai aktivitas yang berlawanan dengan mikroorganisme patogen. Lactobacillus merupakan salah satu genus bakteri asam laktat dan dapat dijumpai pada saluran gastro-intestinal pada manusia. Tujuan penelitian ini untuk mengetahu Aktivitas Antimikroba Lactobacillus dari feses Bayi terhadap Bakteri patogen. Metode penelitian ini bersifat deskriptif. Biakan Lactobacillus sp. dari feses bayi diisolasi dan diidentifikasi kemudian dilakukan uji aktivitas antimikroba dari filtrat Lactobacillus sp. terhadap Salmonella typhi. Metode uji antibakteri yang digunakan adalah metode sumuran dengan melihat zona hambat pertumbuhan bakteri di sekitar sumuran. Hasil penelitian ini memperlihatkan adanya zona bening pada sampel yang positif Lactobacillus sp dengan dibuat konsentrasi filtrat 50\%,75\%, dan 100\% pada pertumbuhan Salmonella typhi dengan diameter zona hambat yang terbentuk pada sampel N9 pada pengenceran $50 \%(9 \mathrm{~mm}), 75 \%(12 \mathrm{~mm})$, $100 \%$ (13 mm). Lalu pada sampel C9 pengenceran 50\% $12 \mathrm{~mm}, 75 \% 14 \mathrm{~mm}$, dan 100\% (15 mm). Sedangkan pada sampel N10 pengenceran 50\% (0,7 mm), 75\% (13 mm), dan 100\% (14 mm). Dari hasil tersebut dapat disimpulkan Bakteri Lactobacillus sp yang diisolasi dari feses bayi dapat menghasilkan antimikroba yang dapat menghambat pertumbuhan Salmonella thypi sebagai bakteri patogen.
\end{abstract}

Kata kunci: Bakteri asam laktat, Lactobacillus, Antimikroba, Salmonella typhi

\begin{abstract}
Lactic acid bacteria have been used as food preservatives, fermentation cultures and probiotic foods because they oppose to pathogenic microorganisms. Lactobacillus is one of the genera of lactic acid bacteria and can be found in human gastrointestinal tract. The purpose of this study was to investigate the Lactobacillus Antimicrobial Activity in Infant Stools against Pathogenic Bacteria. This research method is descriptive. Lactobacillus sp. of the infant stool was isolated and then identified with antimicrobial activity test of the Lactobacillus sp filtrate against Salmonella typhi. The antibacterial test method used is the wellbore method by looking at the bacterial growth inhibition zone around the well. The results of this study showed a clear zone in a positive sample of Lactobacillus $s p$ with $50 \%, 75 \%$, and $100 \%$ filtrate concentration on Salmonella typhi growth with drag zone diameters formed on $\mathrm{N} 9$ samples at $50 \%$ dilution of $(9 \mathrm{~mm}), 75 \%(12 \mathrm{~mm}), 100 \%$ $(13 \mathrm{~mm})$, on sample C9 dilution $50 \%(12 \mathrm{~mm}), 75 \%(14 \mathrm{~mm})$, and 100\% $(15 \mathrm{~mm})$. While on sample N10 dilution $50 \%(0,7 \mathrm{~mm}), 75 \%(13 \mathrm{~mm})$, and $100 \%(14 \mathrm{~mm})$. From these results, it can be concluded that Lactobacillus sp bacteria isolated from baby's feces can produce antimicrobials that can inhibit Salmonella thypi growth as pathogenic bacteria.
\end{abstract}

Keywords: Lactic acid bacteria, Lactobacillus, Antimicrobial, Salmonella typhi

Open Journal System (OJS): journal.thamrin.ac.id

http://journal.thamrin.ac.id/index.php/anakes/issue/view/43 


\section{PENDAHULUAN}

Bakteri asam laktat didefinisikan sebagai kelompok bakteri yang membentuk asam laktat, baik sebagai satu-satunya produk maupun sebagai produk utama pada metabolisme karbohidrat. Beberapa ciri yang dimiliki oleh bakteri asam laktat adalah termasuk dalam Gram positif, tidak membentuk spora, berbentuk bulat atau batang, dan pada umumnya tidak memiliki katalase. Bakteri asam laktat banyak ditemukan pada produk makanan olahan, baik produk hewani seperti daging dan ikan yang difermentasi, susu fermentasi, maupun pada produk nabati seperti fermentasi sayuran dan buah-buahan. Selain itu bakteri asam laktat juga banyak terdapat pada organ dalam makhluk hidup, seperti pada saluran pembuangan, jalur genital, jalur intestin, maupun jalur respiratori pada manusia dan hewan (Hassan, 2016).

Bakteri asam laktat telah digunakan sebagai pengawet makanan, kultur fermentasi dan pangan probiotik karena mempunyai aktivitas yang berlawanan dengan mikroorganisme patogen dan pembusuk makanan. BAL mampu memproduksi asam organik, metabolit primer dan menurunkan $\mathrm{pH}$ lingkungannya dengan mengekresikan senyawa yang mampu menghambat mikroorganisme patogen seperti hidrogen peroksida (H2O2), diasetil, CO2, asetaldehid, D-isomer asam-asam amino, dan bakteriosin (Utami, 2011). Didasarkan pada klasifikasi bakteri asam laktat revisi terbaru, ada 10 genera yang termasuk dalam kelompok bakteri asam laktat, yaitu Aerococcus, Carnobacterium, Enterococcus, Lactobacillus, Lactococcus, Leuconostoc, Pediococcus, Streptococcus, Tetragenococcus, dan Vagococcus (Setianingsih, 2010; Hassan, 2016).

Lactobacillus merupakan salah satu genus bakteri asam laktat yang paling banyak dijumpai pada saluran gastro-intestinal baik pada manusia maupun pada hewan. Pada usus halus, jumlahnya dapat mencapai $10^{6}-10^{7} \mathrm{sel} / \mathrm{g}$, sedangkan pada usus besar jumlahnya berkisar antara $10^{10}-10^{11} \mathrm{sel} / \mathrm{g}$. Beberapa spesies Lactobacillus telah banyak diisolasi dari saluran usus halus manusia dan hewan. Beberapa diantaranya adalah Lactobacillus acidophilus, Lactobacillus reuteri, Lactobacillus lactis, Lactobacillus casei, dan Lactobacillus fermentum. Dari beberapa spesies tersebut diatas, Lactobacillus acidophilus merupakan bakteri asam laktat yang paling dominan dan paling banyak dipelajari (Hontong dkk., 2015; Hassan, 2016). 
Penelitian tentang isolat bakteri asam laktat telah banyak dilakukan terutama pada bakteri Lactobacillus sp. Yang diisolat dari organ dalam makhluk hidup seperti hewan atau manusia, dan pada produk makanan olahan baik pada produk hewani maupun produk nabati. Seperti penelitian yang dilakukan oleh Purwamdhani (1998) telah berhasil mengisolasi bakteri asam laktat dari feses bayi berumur 1-2 bulan sebanyak 11 isolat, 8 isolat diidentifikasi sebagai Lactobacillus acidophilus dan 3 isolat lainnya merupakan Lactobacillus reuteri. Menyatakan bahwa isolat yang diidentifikasi Lactobacillus acidophilus memiliki kemampuan menghambat bakteri patogen lebih efektif dibanding dengan isolat yang diidentifikasi sebagai Lactobacillus reuteri. Berdasarkan landasan diatas penulis tertarik untuk melakukan penelitian aktivitas antimikroba Lactobacillus $s p$ yang di isolasi dari feses bayi terhadap Salmonella typhi.

\section{METODE PELAKSANAAN}

Metode penelitian ini bersifat deskriptif. Biakan Lactobacillus sp. dari feses bayi diisolasi dan diidentifikasi kemudian dilakukan uji aktivitas antimikroba dari filtrat Lactobacillus sp. terhadap Salmonella typhi. Sampel yang dipilih dalam penelitian ini adalah koloni hasil isolasi Lactobacillus sp. dari feses bayi yang memiliki kriteria inklusi berumur 0-7 hari dengan persalinan normal dan operasi sesar yang terlahir sehat, tidak ada indikasi cacat berarti, tidak ada indikasi penyakit yang membahayakan bayi. Sedangkan kriteria eksklusinya bayi yang mengomsumsi antibiotik, kelainan bawaan (detak jantung tidak normal). Pada penelitian ini teknik yang digunakan yaitu dengan pengumpulan koloni Lactobacillus sp hasil isolasi dari feses Bayi yang berumur 0-7 hari. Menggunakan media MRSA pengolahan analisis data dilakukan dengan menghitung Zona hambat hasil Uji Aktivitas Antimikroba dari filtrat Lactobacillus sp terhadap Salmonella typhi.

\section{HASIL DAN PEMBAHASAN}

Berdasarkan penelitian yang dilakukan, didapatkan masing-masing 10 sampel feses bayi yang lahir secara normal dan secara sesar di Rumah Sakit X. Lalu semua sampel dilakukan penanaman pada media De man, Rogosa, sharpe Agar (MRSA) yang dilakukan oleh peneliti sebelumnya. Semua sampel feses bayi yang ditanam pada MRSA didapatkan 95\% koloni yang tumbuh memiliki ciri-ciri ke arah koloni Lactobacillus sp., 
sedangkan 5\% tidak mengalami pertumbuhan koloni. Selanjutnya dilakukan identifikasi Lactobacillus sp menggunakan pewarnaan Gram dan uji katalase. Hasil dapat dilihat pada Gambar 1.

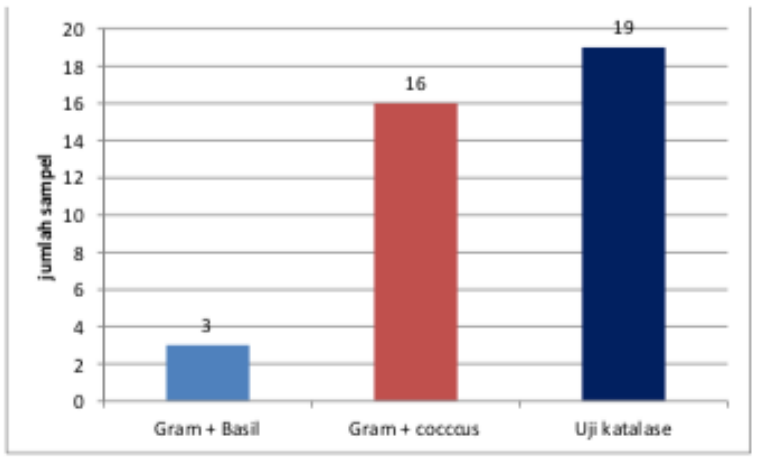

Gambar 1: Hasil Pewarnaan Gram dan Uji Katalase

Sampel yang termasuk Lactobacillus sp adalah sampel dengan hasil pewarnaan Gram berbentuk batang pendek, memiliki sifat Gram positif dan tidak memiliki enzim katalase. Kemudian, hasil pewarnaan Gram berbentuk coccus, memiliki sifat Gram positif dan tidak memiliki enzim katalase termasuk Streptococcus sp. Berdasarkan Gambar 1 diperoleh bakteri yang diduga Lactobacillus sp sebanyak 3 sampel, dan Streptococcus sp. sebanyak 16 sampel seperti pada Gambar 2.

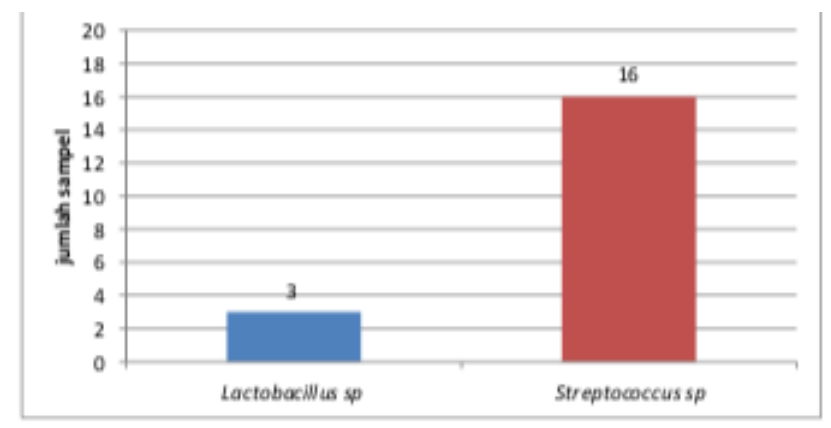

Gambar 2: Hasil Identifikasi Lactobacillus sp.

Berdasarkan Gambar 2 hasil identifikasi didapat 3 sampel yang diduga Lactobacillus sp (N9,C9, dan C10). Kemudian sampel Lactobacillus sp dilakukan penanaman ulang kemedia De man, Rogosa, Sharpe Broth (MRSB) dan MRSA, sedangkan yang diduga Streptococcus sp tidak dilanjutkan. Setelah dilakukan penanaman pada media MRSB dan MRSA sampel (N9,C9, dan C10) dilakukan pemisahan untuk diambil filtratnya, kemudian dilakukan uji Aktivitas Antimikroba terhadap Salmonella 
thypi pada media Muller Hinton Agar (MHA) dengan menggunakan metode difusi sumuran. Zona jernih yang dihasilkan ditujukan sebagai kemampuan penghambatan bakteri uji terhadap bakteri patogen seperti pada Gambar 3.

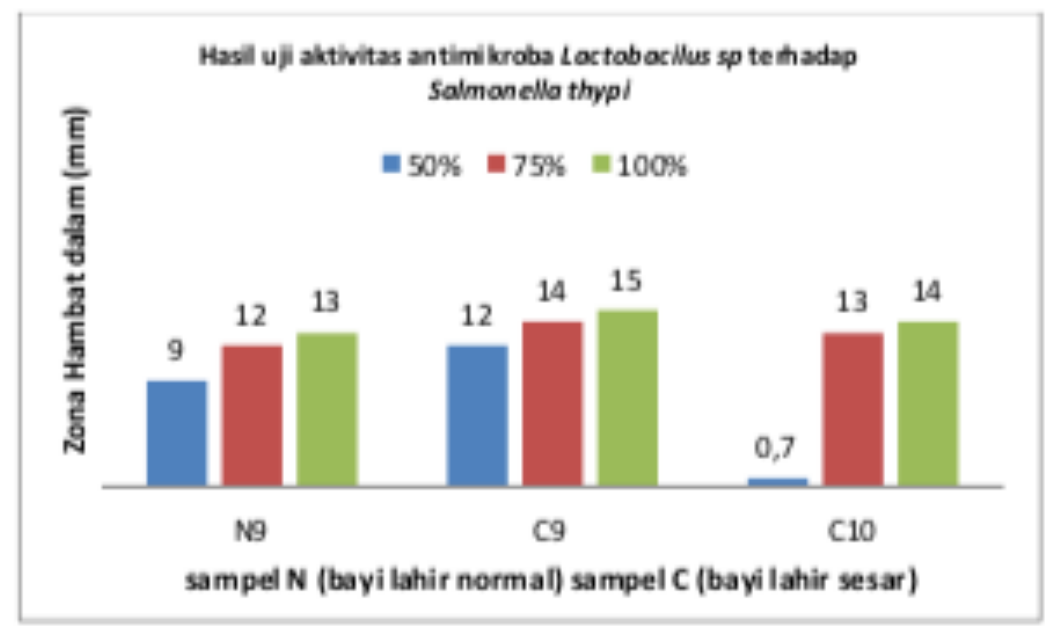

Gambar 3: Zona Hambat Lactobacillus sp. Terhadap Salmonella thypi

Sampel yang digunakan pada penelitian ini yaitu sampel feses bayi yang berumur 1-7 hari di Rumah Sakit X. Menurut Penelitian Hasan (2016) Bakteri asam laktat banyak terdapat pada organ dalam makhluk hidup, seperti pada saluran pembuangan, jalur genital, jalur intestin, maupun jalur respiratori pada manusia, salah satunya Lactobacillus yang merupakan genus bakteri asam laktat yang paling banyak dijumpai pada saluran gastro-intestinal pada manusia. Pada usus halus, jumlahnya dapat mencapai $10^{6}-10^{7}$ $\mathrm{sel} / \mathrm{g}$, sedangkan pada usus besar jumlahnya berkisar antara $10^{10}-10^{11} \mathrm{sel} / \mathrm{g}$.

Pada bayi sendiri sebelum dilahirkan, saluran pencernaan bayi masih dalam keadaan steril. Pada saat bayi dikeluarkan melalui vagina, kolonisasi mikrobiota natural pada bayi pertama kali berasal dari vagina maupun saluran pencernaan ibunya. Dalam perkembangannya, asupan makanan bayi berperan penting terhadap mikrobiota saluran pencernaannya. Selama masa menyusui, komposisi mikrobiota saluran pencernaan berkembang dalam jangka waktu yang singkat, dan didominasi oleh Bifidobacteria (Boehm dan Moro, 2008).

Menurut penelitian Setianingsih (2010), menyatakan bahwa pada Air Susu Ibu (ASI) yang keluar sejak hari pertama ibu yang melahirkan sampai hari ketujuh (bisa juga sampai hari ke 10). Di dalam terdapat banyak sekali zat gizi yang sangat diperlukan oleh 
bayi, salah satunya adalah faktor bifidus, yaitu sejenis karbohidrat yang mengandung nitrogen dan dapat menunjang pertumbuhan bakteri Lactobacillus bifidus. Ditemukan juga strain B. bifidum (yang kemudian dikenal sebagai L. bifidus) di dalam ASI, khususnya karena keberadaan $\mathrm{N}$ - acetylglucosamine. Di dalam ASI juga terdapat glikoprotein yang juga dapat meningkatkan pertumbuhan BAL. Selain itu ASI juga mengandung laktoferin, yaitu protein yang berikatan dengan zat besi. Dengan mengikat zat besi, maka laktoferin dapat menunjang pertumbuhan BAL dan menghambat pertumbuhan bakteri tertentu, seperti Staphylococcus aureus dan Escherichia coli.

Pada penelitian ini dari 20 sampel didapatkan 19 sampel yang tumbuh dimedia De man, Rogosa, sharpe Agar (MRSA) yaitu media untuk memperkaya atau menumbuhkan jenis Lactobacillus sp yang mengandung polysorbat, asetat, magnesium, dan mangan yang diketahui sebagai faktor pertumbuhan bagi Lactobacillus, akan tetapi MRSA tidak sangat selektif, sehingga ada kemungkinan jenis bakteri asam laktat lain dapat tumbuh, maka dilakukan uji konfirmasi dengan melihat morfologi sel dengan pewarnaan gram yang bertujuan untuk mengetahui bentuk, susunan dan sifat dari bakteri uji. Serta uji katalase untuk mengetahui aktivitas katalase bakteri yang diuji. Dari hasil pewarnaan gram dan uji katalase didapatkan 3 sampel yang positif Lactobacillus sp yaitu (N9, C9, dan C10) seperti yang tertulis didalam buku Pleczar \& Chan (2007) bahwa Morfologi sel Lactobacillus sp yaitu berbentuk batang pendek, tidak berspora, tidak berflagel, tidak berkapsul, sifat Gram positif dan tidak memiliki enzim katalase. Hasil pewarnaan pada sampel N9, C9, dan C10 didapatkan bakteri dengan ciri-ciri batang pendek, susunan berantai, dengan sifat bakteri Gram positif dan tidak memiliki katalase. Kemudian pada sampel yang tersangka Lactobacillus sp dilakukan uji Aktifitas antimikroba terhadab bakteri Salmonella thypi. dari filtrat Lactobacillus sp. terhadap Salmonella typhi.

Metode uji antibakteri yang digunakan adalah metode sumuran dengan melihat zona hambat pertumbuhan bakteri di sekitar sumuran. Menurut Lourens-Hattingh dan Viljoen (2001), Lactobacillus sp menghasilkan beberapa metabolit antara lain asam laktat, asam asetat, dan bakteriosin yang mampu menghambat pertumbuhan bakteri patogen. Dengan mekanisme aktivitas penghambatan antimikroba menurut Davidson dan Brannen (Rastina dkk., 2015), dapat melalui beberapa faktor, antara lain: (1) mengganggu komponen penyusun dinding sel, (2) bereaksi dengan membran sel sehingga 
mengakibatkan peningkatan permeabilitas dan menyebabkan kehilangan komponen penyusun sel, (3) menginaktifkan enzim esensial yang berakibat pada terhambatnya sintesis protein dan destruksi atau kerusakan fungsi material genetik.

Seperti yang terdapat pada Gambar 3 dengan menggunakan metode difusi sumuran filtrat yang dihasilkan Lactobacillus sp dapat menghambat pertumbuhan Salmonella thypi. dengan diameter zona hambat yang terbentuk pada sampel N9 pada pengenceran $50 \%(9 \mathrm{~mm}), 75 \%(12 \mathrm{~mm}), 100 \%(13 \mathrm{~mm})$. Lalu pada sampel C9 pengenceran $50 \%(12 \mathrm{~mm}), 75 \%(14 \mathrm{~mm})$, dan 100\% (15mm). Sedangkan pada sampel N10 pengenceran 50\% (0,7mm), 75\% (13mm), dan 100\% (14mm). Penelitian Rastina dkk. (2015) dan Suryani (2012), mengatakan bahwa kemampuan suatu antimikroba dalam menghambat mikroorganisme tergantung pada konsentrasi bahan antimikroba dan jenis bahan antimikroba yang dihasilkan.

Semakin besar konsentrasi suatu antimikroba, maka semakin besar zona bening yang terbentuk. Hal ini disebabkan karena semakin tinggi konsentrasi bahan antimikroba, maka semakin banyak zat aktif yang terkandung di dalamnya sehingga efektivitas dalam menghambat bakteri akan semakin meningkat dan menghasilkan zona bening yang lebih luas. Sedangkan Davis \& Stout (2009) membagi kekuatan daya antimikroba menjadi empat kategori, yaitu menghambat lemah ( $<5 \mathrm{~mm})$, sedang $(5-10 \mathrm{~mm})$, kuat (10-20 mm), dan sangat kuat (>20 mm). Pada penelitian ini, daya hambat antimikroba dari filtrat yang dihasilkan Lactobacillus sp pada sampel C10 konsentrai 50\% termasuk kedalam kategori lemah, pada sampel N9 konsentrasi 50\% termasuk kedalam kategori sedang, dan pada konsentrasi 75\% 100\% sampel (N9,C9,C10) dan sampel C9 konsentrasi 50\% termasuk dalam kategori kuat. Zona bening yang terbentuk disebabkan adanya senyawa antibakteri yang terdapat dalam filtrat Lactobacillus sp seperti asam laktat, asam asetat, dan bakteriosin. Adapun menurut Taufik (2012) dan Susilawati (2016), aktivitas antimikroba asam laktat, asam asetat, dan bakteriosin terhadap bakteri patogen dipengaruhi oleh struktur dinding sel bakteri patogen.

\section{SIMPULAN}

Bakteri Lactobacillus sp yang diisolasi dari feses bayi dapat menghasilkan antimikroba yang menghambat pertumbuhan Salmonella typhi dengan adanya zona hambat yang terbentuk. 


\section{REFERENSI}

Anindita, N. S., Anwar, M., Taufiq, T. T., Widodo, \& Wahyuningsih, T. D. (2017). Ketahanan isolat Bakteri Asal Feses Bayi Terhadap Variasi Suhu dan pH. Proceeding Health Architecture, 1:163-169.

Djide, M., \& E., W. (2008). Isolasi Bakteri Asam Laktat dari Air Susu ibu dan Potensinya Menurunkan Kadar Kolesterol secara In-vitro. Farmasi dan Farmakologi, 12(3):73-78.

Hassan, Z. H. (2016). Isolasi Lactobacillus, Bakteri Asam Laktat dari Feses dan Organ Saluran Pencernaan Ayam. Seminar Nasional Teknologi Veteriner, 735-736.

Hontong, M. F., Warouw, S. M., Manoppo, J. I., \& Salendu, P. (2015). Hubungan Mikroflora Usus pada Bayi Baru Lahir dengan Jenis Persalinan. Sari Pediatri, Vol 17 No.1, 25-27.

Herawati I, \& Fauziah P.N. (2016). Modul Praktikum Mikrobiologi II. Cimahi: STIKES A.Yani.

Purwandhani, S. N. (2007). Isolasi dan Seleksi Lactobacillus yang Berpotensi Sebagai Agensia Probiotik. Yogyakarta: Tesis Program Pascasarjana Universitas Gadjah Mada.

Rastina, Sudarwanto M, Wientarsih I. (2015). Aktivitas Antibakteri Ekstrak Etanol Daun Kari (Murraya koenigii) Terhadap Staphylococcus aureus, Escherichia coli, dan Pseudomonas sp. Jurnal Kedokteran, vol 9 (2): 185- 188.

Setianingsih, S. (2010). Kajian Senyawa Antimikroba Bakeri Asam Laktat Homofermentatif Isolat Asi. Skripsi. Bogor: Defertemen Ilmu dan Teknologi Pangan Fakultas Teknologi Institusi Pertanian Bogor.

Sunaryanto, R., Martius, E., \& Marwoto, B. (2014). Uji Kemampuan Lactobacillus casei sebagai Agensia Probiotik. Jurnal Bioteknologi \& Biosains Indonesia, 9-15.

Surono, I. (2004). Probiotik Susu Fermentasi dan Kesehatan. Jakarta: PT. Tri Cipta Karya. 
Suryani, \& dkk. (2017). Identifikasi Molekular Bakteri Asam Laktat Lactobacillus paracasei yang Ada pada Lapisan Minyak VCO. Jurnal Katalisator, 2(1):79- 82.

Susilawati, S. (2016). Isolasi dan Karakterisasi Bakteri Asam Laktat (BAL) dari Fermentasi Air Cucian Beras, Skripsi. Jakarta: Fakultas Kedokteran dan Ilmu Kesehatan.

Taufiq, T. T. (2012). Isolasi dan Identifikasi Isolat Bakteri Asam Laktat dari Feses Bayi dan Evaluasi In Vitro Potensi Probiotik. Yogyakarta: Universitas Gadjah Mada. 